\title{
Do Golden Parachutes Increase CEO's DESIRE to Be Taken Over? Empirical Evidence from Australia and United States
}

\author{
Krishna Reddy KR (corresponding author) \\ Department of Finance, University of Waikato, New Zealand \\ E-mail:krishna@waikato.ac.nz \\ Sazali Abidin \\ Department of Finance, University of Waikato, New Zealand \\ E-mail: sazali@waikato.ac.nz \\ Caillor Woon \\ Department of Finance, University of Waikato, New Zealand \\ E-mail: ciw2@waikato.ac.nz
}

Received: May 29, 2012 Accepted: July 25, 2012 Published: December 1, 2012

doi:10.5296/ajfa.v4i2.1871 URL: http://dx.doi.org/10.5296/ajfa.v4i2.1871

\begin{abstract}
This study investigates whether the large payouts that are available to Chief Executive Officers (CEOs) from a change in corporate control (takeover) do motivate some CEOs to seek acquisition of their firms by making them more attractive to a takeover bid. Using Australian and the US data, employing OLS regression, we report that there is a significant relationship between a CEOs change in control payments and their firm's net cash levels (one of the key factors of takeover attractiveness). Our empirical results also indicate that CEOs desire their firms to be acquired by decreasing shareholders' equity, thus supporting the view that change in control payments exist primarily for incumbent managers. Our findings provide support to the proposition that managers enjoy having large cash balances to be available to them as it allows them with greater opportunities to derive personal benefit from
\end{abstract}


it. Therefore, our findings suggest that managers prefer to have large cash balances available to them to ensure their future wellbeing by setting up favourable terms in the control agreements.

Keywords: change in control payments, takeover attractiveness, equity holding, mergers and acquisitions, agency theory

JEL Classifications: G34, G35 


\section{Introduction}

Media and popular opinions view managers of publicly listed companies as self-seekers, primarily out for their own gain at the expense of the shareholders (Smith, 2009). A prime example of such behaviour is observed in the mergers and acquisitions market. Chief Executive Officers (CEOs) that acquire other firms increase their own salaries while CEOs whose firms are taken over receive highly lucrative payouts (Grinstein and Hribar, 2004). Lucrative payouts are termed 'change in control payments' and have become so large that it is nine times a CEO's annual salary (on an average basis) (Hartzell, Ofek and Yermack, 2004). In some cases, the change in control payment is similar to winning a first prize in a state lottery. The change in control payments is referred as 'golden parachute' (Hartzell et al, 2004) which is the payment made to the acquired firm's CEO for terminating employment through no fault of their own. Termination of employment often arises when mergers and acquisitions takes place and the change in control payments allow CEOs of acquired firms to be financially unharmed, hence the name, golden parachutes. Bebchuk, Cohen and Wang (2010) report that the presence of golden parachute increases the likelihood of takeover bids by 245.4 per cent and increases the likelihood of acquisition by 28.4 per cent.

The two key factors that make takeovers attractive are firm's net cash levels and debt capacity (Powell and Thomas, 1994). However, a firm's net cash balance and change in control payments are both depended on the managerial power. Jenson (1986) provided a link between managerial power and net cash balance by showing that firms with greater cash levels provide greater opportunities for CEOs to gain personally through perks such as company cars and large office space.

However, the focus of the extant literature has been on investigating whether golden parachutes reduce risks for CEOs (Morrison, 1982; Maurer, 1984) or remove a CEO's motivation to sabotage an external takeover attempt (Morrison, 1982; Larcker and Lambert, 1985). Therefore, little research has been undertaken to date that investigates whether the potential gains from golden parachutes actually motivate some CEOs to desire their firm to be taken over. This study is novel as it investigates whether the size of a change in control payments have become so large that it influences CEOs to actually desire their firm's to be taken over.

This study contributes to the literature in three distinct areas relating to finance that are, mergers and acquisitions, corporate governance and capital structure. First, most studies relating to mergers and acquisitions argue from the acquiring firm's viewpoint, that is, whether acquisitions are a wise investment or they simply exist to increase the acquiring CEOs power (see Holland and Hodgkinson, 1994; Andrade, Mitchell \& Stafford, 2001). However, the research question that we propose "Do golden parachutes increase CEO's desire for their firms to be taken over?" allows mergers and acquisitions to be viewed from the target firms' perspective. If golden parachutes do increase CEOs desire for their firms to be taken over, it will have important implications for corporate governance issues and the board of directors will be interested to know what impact a CEO's motivation to seek acquisition will have on their firm. Moreover, shareholders may desire their firm to be taken 
over for the reasons of the equity premiums as well. Therefore, it would be important to know if shareholders' motivation for the merger and acquisitions is in fact aligned with the CEO's desire to be taken over. Furthermore, the desire to be taken over may actually motivate CEO's to alter the capital structure of their firm in such a way that it becomes attractive for takeovers (Powell and Thomas, 1994). Finally, studies relating to mergers and acquisition have mainly been based on the UK or the US markets and therefore, little is known about the managerial behaviour relating to golden parachutes outside these countries. For our research, we include data from both Australia and the US which adds to our understanding regarding the effect of golden parachutes on CEOs motivation on a global basis.

Our results show a positive association between net cash balances and golden parachutes, which to some extent explain the effects golden parachutes have on CEOs desire to be taken over. Our findings suggest that CEOs with power not only enjoy greater levels of cash but also ensure that their future financial wellbeing is taken care of by locking in large change in control payments. This finding is also supported by Jensen (1986), who state that the large change in control payments not only motivates CEOs to seek acquisition but also exists as an insurance policy for the incumbent manager against the acquisition market.

The rest of this paper is organised as follows. Section II provides reviews of the extant literature on the subject of change in control payments. Section III provides the problem definition and motivation. Section IV describes the data sources and research method. Section V presents the empirical results and Section VI, conclusion.

\section{Literature Review}

The term 'golden parachute' stems from a broader field of corporate governance. For this reason, a majority of scholars have used agency theory paradigm to investigate the effects of golden parachutes on firm performance. Many researchers (see Grinstein and Hribar, 2004 for details) have focused on acquirers; while a few have also studied the effect of golden parachute on the acquired firms as well (Hartzell et al., 2004). Morrison (1982) argues that CEOs whose firms are acquired often lose jobs which motivate them to find ways to reduce the possibility of such acquisitions. There are numerous options available to the CEOs and one of the most popular one is to delay and hinder progress of a takeover bid by influencing shareholders. Over the last decade or so only 18 per cent of the takeovers were hostile (Hartzell, et al., 2004), which indicate that most of the takeovers do require support of the incumbent managers to progress. Furthermore, empirical evidence show that acquisitions have largely benefited target companies shareholders (Loughran and Vijh, 1997; Holland and Hodgkinson, 1994) and therefore, by resisting takeover attempts, CEOs can cost acquiring shareholders significant acquisition premiums. Minimizing the cost of the conflict between a CEOs desire to keep their job and shareholders' wealth maximisation is one of the major reason for the existence of golden parachutes. Golden parachutes allow managers to objectively review takeover offers without having to be concerned about their own financial security, thus reducing agency costs (Morrison, 1982). Larcker and Lambert (1985) argue that golden parachutes allow firms to realign incentives of the CEOs with that of the shareholders. In support, Born and Trahan (1993) state that golden parachutes have a positive effect on 
firms' share prices, especially when a firm is previously considered to be 'out of play', that is, unlikely to be involved in a takeover. Therefore, the likelihood of takeover increases in firms that have golden parachutes (Machlin, Choe and Miles, 1993). Furthermore, takeovers provide larger premiums to the target firm's shareholders that have golden parachutes in place compared to firms without golden parachutes. Other benefit of golden parachutes include firms ability to acquire and retain talented executives (Morrison, 1982); Maurer, 1984).

However, Knoeber (1986) and Narayan and Sundaram (1998) state that golden parachutes are required by managers to hedge the risk associated with their employment contracts. Firms that have golden parachutes are on an average riskier than firms without golden parachutes (Almazan and Suarez, 2004; Narayan and Sundaram, 1998) and therefore, golden parachutes enable firms to have access to managers who otherwise see their position to be too risky ( Pfeffer, 1973; Provan, 1980).

Firms without golden parachutes poses greater levels of risk compared to firms that have golden parachutes in place. For example, a firm without golden parachute will find it difficult to attract high achieving executives as they will not be willing to leave their existing firms which have golden parachutes. This is especially of concern for poor performing firms which are more likely to be the target of takeovers due to their relatively low cost. Moreover, current executives in firms without golden parachutes may leave in order to find employment in firms that have a greater financial security. For this reason, the likelihood of a manager leaving a firm increases during a takeover offer, thus leaving firm without a leader and making shareholders' vulnerable (Maurer, 1984).

To the contrary, Whisler (1984), Drucker (1974) and Lorsch (1989) argue that golden parachutes are forced on boards and shareholders who lack control of the firm. Managers that desire greater security for their financial wellbeing force their boards to give them assurances in the form of golden parachutes. Larcker and Lambert (1985) suggest that golden parachutes allow poor performing managers to shield themselves from the market discipline. Wade and O'Reilly (1990) reported that CEOs appoint more outsiders to the board so that they have a higher incidence of golden parachutes. Therefore, findings reported by Whisler (1984), Drucker (1974), Lorsch (1989), Larcker and Lambert (1985) and Wade and O'Reilly (1990) provide support to the view that CEOs who have more power on their firm have a higher tendency to use this power to ensure their financial future is secured through the use of golden parachutes. Furthermore, Domhoff (1978) and Ratcliff (1980) argue that golden parachutes are a pat on the back from the board of directors to the CEOs who are the members of the same social class. Such activities are often reported in the popular media and are referred to as corporate back scratching. Moreover, Singh and Harianto (1989) state that firms with golden parachute agreements have a higher tendency to have diffused share ownership structure, thus leading to greater board control. They also report that golden parachutes are related to greater CEO tenure relative to board tenure and having more external directors.

According to Bowie and Fischer (1996), the benefits from golden parachutes are so large that they may encourage CEOs to actively solicit takeover regardless of the effect it has on the 
shareholders. One of the largest sources of change in control payments for target CEOs is the equity premiums. When a firm is the target of a takeover, the acquiring firm is forced to pay equity premium to ensure that they are able to purchase a controlling stake in the firm (Loughran and Vijh, 1997). CEOs that hold large portions of a firm's equity (due to stock options and the like) often gain substantially from the equity premium involved with a takeover (Hartzell et al., 2004).

Hartzell et al. (2004), reported that on average, a target CEOs change in control payments are worth US\$12 million, or nine times their annual salary, with one CEO in their sample even earning two hundred times his annual income. Around 80 per cent of CEOs whose firms are acquired in their sample ceased paid work, either retired or moved into a non-profit sector. Based on the findings reported by Hartzell et al. (2004), Maurer (984) and Bowie and Fischer (1996), we argue that large gains that are potentially available to CEOs under a change in control payments may indeed cause CEOs to desire their firms to be taken over.

\section{Change in Control Payment, Takeover Attractiveness and Control Variables}

To determine if substantial change in control payments causes CEOs to desire their firm to be taken over, we examine whether CEOs who stand to gain substantially from acquisitions are also in charge of firms which are more attractive to takeover bids. Similar to Simons (2002), we also examine whether CEOs desire to be taken over by looking at their actions. The view we have taken is that a CEO that has a large golden parachute available to them may get encouraged to desire their firms to be taken over.

Since we are interested in the effects of golden parachute agreements (or potential payouts), our sample include firms that have been acquired and also firms that have large payouts available to CEOs that would motivate them to make their firms more attractive (whether or not a takeover actually eventuates). Our focus is on two variables that have potential to determine whether CEOs who stand to gain substantially from acquisitions are also in charge of firms that are more attractive to takeover bids, that is, the size of a CEO's change in control payments and the attractiveness of the CEO's firm to takeover bids.

\subsection{Change in Control Payments}

Hartzell et al. (2004) report that CEOs on an average receive US\$8 million to US\$11 million as a result of a change in control payments, which is approximately 9 to 16 times their average annual salary. The primary source of the change in control payments are the amount of the equity premium paid by the acquiring firms. Since potential acquirers' pay a premium above a company's market stock price in order to gain control of the firm, stock price of an acquired firm rises which benefits the acquiring firms' shareholders. Firms often pay their CEOs a large portion of their salary as equity to motivate them to improve the value of the firm, so when a firm is acquired and the stock price rises, a target CEO often gains substantially. According to Hartzell et al. (2004), equity premiums account for approximately half of a CEO's gains due to acquisition (or about US\$5 million on average). Hartzell et al. report that golden parachutes are the second largest source and represent about 20 per cent of a CEOs change in control payments, an average of US\$1.5 million. About 69 per cent of 
CEOs in 2004 had golden parachute agreements which required to be paid out should their employment ever be terminated through no fault of their own.

The final major source of change in control payments occurs as a result of negotiations involved in the takeover process itself. Twenty seven per cent of CEOs are able to negotiate an additional takeover bonus worth on an average US\$1.2 million, while 12 per cent manage to negotiate an augmentation to their standing golden parachutes agreement, again worth half a million dollars on an average basis. Additional negotiated bonuses makes up another 20 per cent of the takeover payments given to acquired CEOs. Hartzell et al. (2004) show that a CEO's expected change in control payments, should they be acquired, can be estimated based on their existing equity ownership, change in control payments and an additional bonus worth about one and a half times their annual salary due to the negotiated benefits. Therefore, we use a similar method to Hartzell et al. (2004) to determine whether a CEO could gain substantially from an acquisition of their firm.

\subsection{Takeover Attractiveness}

In determining what makes a firm attractive to a takeover bid, many researchers have analysed firms that have been acquired in order to determine common characteristics that make a firm a likely target for a takeover bid. Motivated by Jensen (1986), many researchers have focused on the view that mergers and acquisitions are a mean of replacing poorly performing managers. Managers that exert large agency costs on their firms eventually lower the value of their firms to such a point that the firm will be acquired at a bargain price and the management team will be replaced. Martin and McConnell (1991), Palepu (1986) and Powell and Thomas (1994) found that firms with low stock performance have an increased likelihood of takeover. Morck Shleifer and Vishny (1989) and Hasbrouck (1985) have reported similar results using Tobin's Q as a measure of firm performance.

To the contrary, Holland and Hodgkinson (1994) found that past performance has no effect on takeover likelihood in the UK. Similarly, Alcade and Espitia (2003) found no support for the view that acquisitions exist to replace incumbent managers in Spanish companies.

The conflicting empirical evidence relating to firm performance and takeover suggest that debate whether takeovers lead to better performance is far from being over. Although poor past performance would reduce a firm's value and make the firm more attractive for a takeover, reducing firm value would be counterproductive to a CEO looking for their firms to be taken over. Since the primary source of change in control payments is the equity premium (Hartzell et al 2004), reducing the value of the firm in order to attract a takeover bid would hurt CEOs own payout as it would reduce the value of their personal equity.

Palepu (1986), Hasbrouck (1985), Ambrose and Megginson (1992), Berger and Ofek (1996) and Aaronovich (1981) find that firm size is a key factor that increases takeover likelihood. They argue that smaller firms are cheaper to buy and as such, are more attractive to takeover targets. However, reducing a firm's size in order to attract a takeover bid would be counterproductive for a CEO who is looking to cash-in on the change in control payments. 
Any reduction in firm size would not only lower the CEO's equity value but would also result in reducing their salary as well (Hartzell et al 2004, Jensen 1986).

Arguably, a CEO wishing to reap the benefits of change in control payments without reducing the value of their own rewards can be achieved through cash and leverage. Palepu (1986), Holland and Hodgkinson (1994), Powell and Thomas (1994), Lehn and Poulsen (1989) all promote the notion that 'resource rich firms' are more attractive takeover targets. Mergers and acquisitions are often very costly and if firms' that are acquired have large resources available, it can be used to recoup some of the costs of the acquisition. Firms with large cash balances are attractive for takeovers as cash can be used for other projects after acquisition. Likewise, firms with low leverage are attractive as well, excess debt capacity can be utilised by raising debt levels to increase cash balances and help make up for the costly acquisition process. ${ }^{1}$ Once the firm is acquired, the extra cash is used to pay back some of the debt while the rest of the debt is now owed by a much larger combined firm, making the debt comparatively smaller.

Based on the information provided above, we measure a firm's attractiveness to a takeover bid as the value of their cash balances, leverage and as well as a combined factor incorporating both variables.

\subsection{Control Variables}

To determine the effect of the level of payout a CEO is entitled to receive after acquisition, the change in control payments is captured by the variable PayoutFactor. PayoutFactor is an estimate of a CEOs change in control payment divided by their annual compensation. The estimate for the change in control payment is the function of a CEOs shareholding in the existing golden parachutes and the annual compensation is the CEOs annual salary.

PayoutFactor $=\frac{\text { Expected Payout after Acquisition }}{\text { AnnualSalary }}$

Miller and Modigliani (1963) argue that debt generally has a lower cost than equity and therefore, firms should aim to increase their leverage whenever possible. However, a higher debt level leads to greater risk of bankruptcy or financial distress should they be unable to meet their interest obligations. The tradeoff theory states that firms' tradeoff the borrowing costs and bankruptcy costs against each other to arrive at an optimal debt and equity ratio for the firms (Scott, 1976). A key factor that explains a firm's debt level is the firm's financial distress costs. According to John (1993) and Devereux and Schiantarelli (1989), factors affecting firms' financial distress costs are the earnings and cash flow volatility. Essentially firms that have high volatile cash flows are more unlikely to meet their interest obligations in a specific year due to the uncertainty regarding their income. Furthermore, research regarding the reasons for holding high cash balances largely focus on the risk of becoming insolvent. Baumol (1952), Tobin (1956), Meltzer (1963) and Miller and Orr (1966) state that firms hold

\footnotetext{
${ }^{1}$ An extreme case of such takeovers are leveraged buyouts (LBOs) (Damodaran, 2005) where the acquiring firm accrues a large amount of debt in order to acquire a target firm with high cash balances and low leverage.
} 
cash to avoid being short on liquid assets when needed. Moreover, Opler, Pinkowitz, Stulz and Williamson (1999) report that a firm's desire to hold cash is increased when a firm finds it difficult to raise external funds. Therefore, a firm's desire to hold cash can be partly estimated by their volatility of cash flows. Firms with inherently volatile cash flows are more likely to be at risk of insolvency (Miller and Orr, 1966). We also use risk of cash flows as a proxy for the risk of insolvency. To control for the effects of tradeoff theory on debt and risk of insolvency, we include two proxies, that is, firm's volatility of cash flows (FCFVAR) and earnings (NPVAR). FCFVAR is volatility of firm's cash flow over the last three years and NPVAR is the volatility of firm's net profit over the last three years.

Similarly, a high financially performing firm will create more value for the CEO than a low performing firm. To capture the effects of performance on change in control payments, we have used Tobin's Q as a proxy for performance. Tobin's Q is measured as follows:

Tobin's $Q=\frac{\text { Price* No.of Shares Outstanding }+ \text { Net Curent Debt }+ \text { L/T Debt }}{\text { Total Assets }}$

To control for the endogeneity effect, we also use an interaction term (InterQ) which is determined by multiplying FactorPayout by Tobin's Q. ${ }^{2}$

Because CEOs know more about their firm than the outsiders, there is a potential of the existence of information asymmetry when firms apply for outside financing. The pecking order theory postulated by Myers and Majluf (1984) state that executives prefer to fund projects first with cash, then with debt, and use equity as a last resort due to the higher degree of information asymmetry associated with it. Helwege and Liang (1996) and Graham and Harvey (2001) show that more information is known about larger firms and those that pay dividends and therefore, have a lower degree of information asymmetry. Based on this view, we also use both firm size and dividend payout ratio as potential explanation for capital structure. We use natural log of total assets (LnTA) as a proxy for firm size and the ratio of dividend paid divided by net profit of the firm (divPOUT) as a proxy for dividend payout.

Fowley, Hartzell Titman and Twite (2007), state that industry also plays an important part in determining firms' cash balances and capital structure. A firm's industry affects the firm's stability and thus their need to hold cash and financial distress costs. For this reason, we have also included industry dummies in our analysis. We have created seven industry dummy variables where IND is equal to " 1 " if firm belongs to industrials, otherwise " 0 "; HC is equal to " 1 " if firm belongs to Health care, otherwise " 0 "; CS is equal to " 1 " if firm belongs to consumer services, otherwise " 0 "; TECH is equal to " 1 " if firm belongs to technology, otherwise " 0 "; $C G$ is equal to " 1 " if firm belongs to consumer goods, otherwise " 0 "; and $\mathrm{O} \& \mathrm{G}$ is equal to " 1 " if firm belongs to oil \& gas, otherwise " 0 ". The industry the firm belongs to is determined by the Datastream industry identifier.

\footnotetext{
${ }^{2}$ We thank the anonymous reviewers who suggested adding performance measure and as well as an interaction term.
} 
Table 1 provides a summary of the variables used and its measurement.

Table 1. Variable and Measurement

\begin{tabular}{|c|c|}
\hline Variables & Measurement \\
\hline$\%$ Equity & Total equity/Total debt \\
\hline Net cash & $\begin{array}{l}\text { Net cash divided by the firm's total assets. Net cash is the firms' total cash balances } \\
\text { less any cash debts. }\end{array}$ \\
\hline Attractiveness ToTakeover & NetCash $+\%$ Equity \\
\hline CEO share holdings & $\begin{array}{l}\text { Reported SEC value for the chief executives total shares divided by the total } \\
\text { number of shares in the firm. }\end{array}$ \\
\hline $\begin{array}{l}\text { CEO existing golden } \\
\text { parachutes }\end{array}$ & $\begin{array}{l}\text { Reported SEC value for any payments listed as potential payouts under termination } \\
\text { without cause or change of control. The value has been normalised for size by } \\
\text { dividing it by the respective firm's total assets. }\end{array}$ \\
\hline CEO Yearly Salary & $\begin{array}{l}\text { Reported SEC value for the total income of the CEO including expected value of } \\
\text { equity payments. The value has been normalised for size by dividing it by the } \\
\text { respective firm's total assets. }\end{array}$ \\
\hline PayoutFactor & $\begin{array}{l}\text { An estimate of a CEOs change in control payout divided by their annual } \\
\text { compensation. The estimate of change in control payments is a function of CEO } \\
\text { share holdings existing golden parachutes }\end{array}$ \\
\hline LnTA & Natural log of total assets. \\
\hline $\operatorname{divPOUT}$ & $\begin{array}{l}\text { Dividend payout ratio - accounting value for the amount of dividends paid in the } \\
\text { year divided by the total net profit of the firm. }\end{array}$ \\
\hline FCFVar & $\begin{array}{l}\text { Cash flow volatility - volatility over the last three years of the firms accounting } \\
\text { value for total cash flows. }\end{array}$ \\
\hline NPVar & $\begin{array}{l}\text { Earnings volatility - volatility over the last three years of the firms accounting value } \\
\text { for the total net profit of the firm. }\end{array}$ \\
\hline Tobin's Q & $($ Price $*$ No of Shares Outstanding + Net Current Debt + L/T Debt $) /$ Total Assets \\
\hline InterQ & FactorPayout * Tobin's Q \\
\hline Industry & $\begin{array}{l}\text { Firms are divided into seven key industries: industrials (IND), health care (HC), } \\
\text { consumer services (CS), technology (TECH), financials (FINA), consumer services } \\
(\mathrm{CS}) \text {, and oil \& gas (O\&G). }\end{array}$ \\
\hline
\end{tabular}

*Accounting variables sourced from DataStream database, SEC values received from proxy statements from the SEC website.

\section{Data, Methodology and Research Method}

Our sample includes 250 US firms and 100 Australian firms for the financial year 2009 from the S\&P500 and AX200 indices, respectively. Data was collated from three major sources. Accounting data, such as data required to measure firm attractiveness and control variables, was collated from the DataStream database. In the US, firms are required to submit information on CEO compensation and equity ownership in proxy statements to the 
Securities and Exchange Commission and therefore, the change in control payments was collated individually for each firm from the proxy statements. For the Australian companies, executive compensation and security ownership information was collected from individual firms' annual statements.

We use ordinary least squares (OLS) regression to determine the relationship between change in control payments and attractiveness. Three key regression analyses is undertaken: (i) the link between change in control payments and net cash; (ii) the link between change in control payments and debt, and (iii) the link between change in control payments and an attractiveness factor made up of both net cash and debt levels.

Expected change in control payments are estimated based on CEO shareholdings, existing golden parachute agreements and their existing annual compensation similar to that reported by Hartzell et al. (2004). First, the value of the CEOs shareholdings is multiplied by an expected equity premium of 22 per cent based on findings reported Loughran and Vijh (1997) and Holland and Hodgkinson (1994). Second, existing golden parachutes values are then added and are taken at their expected value as found in SEC filings for the US companies or annual report for Australian firms. Hartzell et al. (2004) also find that 27 per cent of CEOs manage to negotiate takeover bonuses equal to 1.5 times their annual salary. Thus, the expected value of this possibility is also added to the expected change in control payments. Finally, Hartzell et al. (2004) shows that 8.6 per cent of CEOs with golden parachutes and 19.3 per cent of CEOs without golden parachutes manage to negotiate an augmentation to their existing golden parachutes agreements. The value of this change in agreements is generally equal to the CEOs annual compensation. The expected value of change in agreements is also added to the CEOs expected change in control payments. The total expected change in control payment is then normalised by dividing it by the CEOs annual salary to make an expected payout factor.

The attractiveness factor is created by examining a firm's relative levels of net cash and debt. Firms are ranked first by net cash/total assets and divided into three groups. The top third of firms are given a net cash score of three, the second third a score of two, and so on. This process is repeated for a firm's debt/total assets. A firm's total attractiveness score is then given by the combination of these two scores. This method of factor creation is similar to that used by Grinstein and Hribar (2004) which enable us to examine separately the link between change in control payments, net cash, debt and total attractiveness.

Our empirical model is formulated a follows:

$$
\begin{aligned}
\text { Change in Control Payments }= & \text { Payoutacot }+ \text { Total Assets }+ \text { divPOUT }+ \text { FCFVar }+ \text { NPVar } \\
& + \text { Industry }+\varepsilon
\end{aligned}
$$

where,

Change in Control Payments = either AttractivenessToTakeover, NetCash or \%Equity 
A firm's AttractivenessToTakeover is a combination of NetCash and \%Equity. NetCash is Net Cash/Total Assets and \%Equity is Total Equity/Total Debt.

\section{Empirical Results}

Table 3 reports the compensation statistics of the sampled firms. Our results show that change in control payments on an average are 11.5 times a CEO's annual salary compared to nine times report by Hartzell et al. (2004). The average salary of a CEO in the US is US\$10.51 million and the average payout is US\$54 million. However, there is a large variation in the actual salary depending on the relative size of the firms. Australian results show similar trend to the US, but is of much lower magnitude. This is not surprising as the firms in Australian are about 50 per cent the size of the US firms when measured by total assets. The mean (median) values for Tobin's Q are 1.53 (1.21) indicate that firms in both countries (Australia and the US) have created value for the shareholders which are greater than one. 
Table 2. Compensation Statistics

\begin{tabular}{|c|c|c|c|c|c|c|c|c|}
\hline Sample & Variable & Units & Mean & Median & Min & Max & S.E & Count \\
\hline \multirow[t]{7}{*}{ All } & $\begin{array}{l}\text { Total } \\
\text { Compensation }\end{array}$ & $\$ M$ & 8.8 & 7.3 & 0.3 & 100.1 & 0.5 & 332 \\
\hline & $\begin{array}{l}\text { Change in } \\
\text { Control }\end{array}$ & $\$ M$ & 14.0 & 10.4 & 0.0 & 125.5 & 1.0 & 332 \\
\hline & Total Shares & M & 5.0 & 1.1 & 0.0 & 217.7 & 1.2 & 332 \\
\hline & $\begin{array}{l}\text { Estimated } \\
\text { Payout }\end{array}$ & $\$ M$ & 45.3 & 24.6 & 0.7 & 1620.6 & 7.1 & 332 \\
\hline & PayoutFactor & $\$$ & 4.7 & 3.9 & 0.3 & 45.7 & 4.6 & 332 \\
\hline & Total Assets & $\$ M$ & 32.2 & 7.9 & 0.1 & 2322.0 & 9.9 & 332 \\
\hline & Tobin's Q & Ratio & 1.53 & 1.21 & 0.50 & 8.32 & 0.94 & 332 \\
\hline \multirow[t]{7}{*}{ AUS } & $\begin{array}{l}\text { Total } \\
\text { Compensation }\end{array}$ & $\$$ & 4.7 & 3.9 & 0.3 & 45.7 & 0.3 & 100 \\
\hline & $\begin{array}{l}\text { Change in } \\
\text { Control }\end{array}$ & $\$ M$ & 7.3 & 5.7 & 0.0 & 57.3 & 0.5 & 100 \\
\hline & Total Shares & M & 2.8 & 0.6 & 0.0 & 99.3 & 0.7 & 100 \\
\hline & $\begin{array}{l}\text { Estimated } \\
\text { Payout }\end{array}$ & $\$ M$ & 25.1 & 13.0 & 0.7 & 739.3 & 3.8 & 100 \\
\hline & PayoutFactor & $\$$ & 5.3 & 1.4 & 0.3 & 576.8 & 2.6 & 100 \\
\hline & Total Assets & $\$ M$ & 17.6 & 2.3 & 0.1 & 617.4 & 8.0 & 100 \\
\hline & Tobin's Q & Ratio & 1.56 & 1.10 & 0.50 & 8.32 & 1.23 & 100 \\
\hline \multirow[t]{7}{*}{ US } & $\begin{array}{l}\text { Total } \\
\text { Compensation }\end{array}$ & $\$ M$ & 10.5 & 8.8 & 0.6 & 100.1 & 0.6 & 232 \\
\hline & $\begin{array}{l}\text { Change in } \\
\text { Control }\end{array}$ & $\$ M$ & 16.8 & 12.5 & 0.0 & 126.0 & 1.1 & 232 \\
\hline & Total Shares & M & 5.9 & 1.4 & 0.0 & 218.0 & 1.4 & 232 \\
\hline & $\begin{array}{l}\text { Estimated } \\
\text { Payout }\end{array}$ & $\$ M$ & 54.00 & 29.6 & 1.6 & 1620.6 & 8.5 & 232 \\
\hline & PayoutFactor & $\$$ & 11.4 & 3.2 & 0.60 & 1264.3 & 5.5 & 232 \\
\hline & Total Assets & $\$ M$ & 38.5 & 10.4 & 0.8 & 2322.0 & 10.7 & 232 \\
\hline & Tobin's Q & Ratio & 1.52 & 1.27 & 0.71 & 6.12 & 0.79 & 232 \\
\hline
\end{tabular}

Table 3 reports the correlation coefficient of the independent variables used in this study. A correlation less than 0.8 are generally considered to be appropriate for regression analysis (Field, 2008). Most of the correlation coefficients reported in Table 3 are less than 0.5, apart for the correlation between the FCFVar and NPVar which is 0.740. Also, our tests for multicollinearity ${ }^{3}$ show that there are no serial correlation issues in the data. Our test for autocorrelation also resulted to be negative as well. We have reported bootstrap standard

\footnotetext{
${ }^{3}$ Not provided. However, results can be obtained from the authors if required. To improve robustness, we have also reported bootstrap standard errors as well.
} 
errors which have a tendency to minimise the effect of heteroskedasticity when sample size is small.

Table 3. Partial Correlation Results for the Independent Variables

PayoutFactor (PF) is an estimate of a CEOs change in control payment divided by their annual compensation and change in control payment is the function of CEOs share holdings in their existing golden parachutes. TA is the natural log of the total assets. NPVAR is the volatility of the last three years of the firms accounting net profit. FCF VAR is the volatility of the last three years firms accounting total cash flows. DivPOUT is the dividends paid in the year divided by total net profit for the firm. Tobin's Q (Q) is the ratio of (Price * No. of shares outstanding + Net Current Debt + L/T Debt) to total assets. IND indicate firm belonging to the Industrial sector, HC indicate Healthcare sector, CS indicate Consumer Services, TECH indicate Technology, FINA indicate Financials, CG indicate Consumer Goods and O\&G indicate Oil and Gas.

\begin{tabular}{|c|c|c|c|c|c|c|c|c|c|c|c|c|c|}
\hline & $P F$ & $T A$ & $N P V A R$ & $\begin{array}{l}F C F \\
V A R\end{array}$ & $\begin{array}{c}\text { Div } \\
\text { POUT }\end{array}$ & $Q$ & $I N D$ & $H C$ & $C S$ & Tech & FINA & $C G$ & $O \& G$ \\
\hline $\begin{array}{l}\text { PayoutFactor } \\
\text { (PF) }\end{array}$ & - & & & & & & & & & & & & \\
\hline $\begin{array}{l}\text { Total Assets } \\
\text { (TA) }\end{array}$ & $\begin{array}{l}-0.0144 \\
(0.794)\end{array}$ & - & & & & & & & & & & & \\
\hline NP VAR & $\begin{array}{l}-0.004 \\
(0.945)\end{array}$ & $\begin{array}{c}-0.185 * * * \\
(0.000)\end{array}$ & - & & & & & & & & & & \\
\hline FCF VAR & $\begin{array}{l}0.004 \\
(0.946)\end{array}$ & $\begin{array}{c}-0.357 * * * \\
(0.000)\end{array}$ & $\begin{array}{c}0.740 * * * \\
(0.000)\end{array}$ & - & & & & & & & & & \\
\hline DivPOUT & $\begin{array}{l}-0.021 \\
(0.708)\end{array}$ & $\begin{array}{l}-0.087 \\
(0.116)\end{array}$ & $\begin{array}{c}0.003 \\
(0.957)\end{array}$ & $\begin{array}{l}-0.031 \\
(0.5790\end{array}$ & - & & & & & & & & \\
\hline & 0.064 & $-0.390 * * *$ & $0.271^{* * *}$ & -0.071 & & - & & & & & & & \\
\hline Q & $(0.248)$ & $(0.000)$ & $(0.000)$ & $(0.199)$ & & & & & & & & & \\
\hline $\begin{array}{l}\text { Industrials } \\
\text { (IND) }\end{array}$ & $\begin{array}{l}-0.019 \\
(0.719)\end{array}$ & $\begin{array}{c}0.066 \\
(0.229)\end{array}$ & $\begin{array}{l}-0.026 \\
(0.637)\end{array}$ & $\begin{array}{l}-0.063 \\
(0.250)\end{array}$ & $\begin{array}{l}-0.075 \\
(0.172)\end{array}$ & $\begin{array}{l}-0.034 \\
(0.543)\end{array}$ & - & & & & & & \\
\hline $\begin{array}{l}\text { Health Care } \\
(\mathrm{HC})\end{array}$ & $\begin{array}{l}-0.016 \\
(0.773)\end{array}$ & $\begin{array}{c}0.059 \\
(0.285)\end{array}$ & $\begin{array}{l}-0.019 \\
(0.722)\end{array}$ & $\begin{array}{l}-0.047 \\
(0.392)\end{array}$ & $\begin{array}{l}-0.079 \\
(0.152)\end{array}$ & $\begin{array}{c}0.237 * * * \\
(0.000)\end{array}$ & $\begin{array}{l}-0.097 \dagger \\
(0.076)\end{array}$ & - & & & & & \\
\hline $\begin{array}{l}\text { Consumer } \\
\text { Services } \\
\text { (CS) }\end{array}$ & $\begin{array}{l}-0.012 \\
(0.825)\end{array}$ & $\begin{array}{l}0.042 \\
(0.442)\end{array}$ & $\begin{array}{l}-0.019 \\
(0.733)\end{array}$ & $\begin{array}{l}-0.045 \\
(0.418)\end{array}$ & $\begin{array}{l}-0.080 \\
(0.145)\end{array}$ & $\begin{array}{c}0.043 \\
(0.438)\end{array}$ & $\begin{array}{c}-0.099 \dagger \\
(0.070)\end{array}$ & $\begin{array}{l}-0.079 \\
(0.148)\end{array}$ & - & & & & \\
\hline $\begin{array}{l}\text { Technology } \\
\text { (TECH) }\end{array}$ & $\begin{array}{l}-0.016 \\
(0.770)\end{array}$ & $\begin{array}{c}0.009 \\
(0.860)\end{array}$ & $\begin{array}{l}-0.021 \\
(0.708)\end{array}$ & $\begin{array}{l}-0.046 \\
(0.401)\end{array}$ & $\begin{array}{l}-0.091 \dagger \\
(0.098)\end{array}$ & $\begin{array}{c}0.118 * * \\
(0.32)\end{array}$ & $\begin{array}{l}-0.102 \dagger \\
(0.064)\end{array}$ & $\begin{array}{l}-0.081 \\
(0.139)\end{array}$ & $\begin{array}{l}-0.083 \\
(0.130)\end{array}$ & - & & & \\
\hline $\begin{array}{l}\text { Financials } \\
\text { (FINA) }\end{array}$ & $\begin{array}{l}-0.019 \\
(0.718)\end{array}$ & $\begin{array}{c}0.296^{* * *} \\
(0.000)\end{array}$ & $\begin{array}{l}-0.026 \\
(0.639\end{array}$ & $\begin{array}{l}-0.070 \\
(0.201)\end{array}$ & $\begin{array}{c}0.041 \\
(0.458)\end{array}$ & $\begin{array}{c}-0.252 * * * \\
(0.000)\end{array}$ & $\begin{array}{c}-0.122 * * \\
(0.027)\end{array}$ & $\begin{array}{l}-0.097 \dagger \\
(0.077)\end{array}$ & $\begin{array}{l}-0.099 \dagger \\
(0.070)\end{array}$ & $\begin{array}{l}-0.102 \dagger \\
(0.064)\end{array}$ & - & & \\
\hline Consumer & -0.017 & 0.008 & -0.021 & -0.041 & -0.044 & -0.017 & $-0.106 \dagger$ & -0.085 & -0.087 & -0.089 & $-0.106 \dagger$ & & \\
\hline Goods (CG) & $(0.753)$ & $(0.880)$ & $(0.701)$ & $(0.447)$ & $(0.422)$ & $(0.761)$ & $(0.054)$ & $(0.115)$ & $(0.108)$ & $(0.108)$ & $(0.054)$ & & \\
\hline Oil \& Gas & -0.014 & $0.121 * *$ & -0.017 & -0.035 & -0.077 & 0.076 & -0.086 & -0.069 & -0.070 & -0.072 & -0.086 & -0.075 & \\
\hline$(\mathrm{O} \& \mathrm{G})$ & $(0.8010$ & $(0.028)$ & $(0.761)$ & $(0.523)$ & $(0.163)$ & $(0.165$ & $(0.118)$ & $(0.211)$ & $(0.201)$ & $(0.192)$ & $(0.118)$ & $(0.174)$ & - \\
\hline
\end{tabular}

$* * *$ denote significance at $1 \%$ level, $* *$ denote significance at $5 \%$ level and $\dagger$ denote significance at $10 \%$ level.

In determining whether a $\mathrm{CEO}$ has potentially attempted to make their firm more attractive as a takeover target, we regress three exogenous attractiveness variables (NetCash or \%Equity, AttractivenessToTakeover) against the potential payout given to a CEO under acquisition. 
Table 4 report the results of the regression analysis between a firm's net cash/total assets as the dependent variable.

Table 4. Net Cash Regression Estimate

\begin{tabular}{|c|c|c|c|c|c|c|}
\hline & US & $\begin{array}{c}\text { BootstrapSt } \\
\text { d. Errors }\end{array}$ & AUS & $\begin{array}{c}\text { Robust Std. } \\
\text { Errors }\end{array}$ & Combined & $\begin{array}{c}\text { Bootstrap } \\
\text { Std. Errors }\end{array}$ \\
\hline Intercept & $\begin{array}{c}0.201 \dagger \\
(1.85)\end{array}$ & 0.127 & $\begin{array}{c}0.499 * * \\
(2.23)\end{array}$ & 0.223 & $\begin{array}{c}0.433 * * * \\
(3.19)\end{array}$ & 0.136 \\
\hline $\begin{array}{l}\text { Payout } \\
\text { Factor }\end{array}$ & $\begin{array}{c}0.001 * * * \\
(4.74)\end{array}$ & 0.000 & $\begin{array}{c}0.013 \dagger \\
(1.76)\end{array}$ & 0.011 & $\begin{array}{c}0.001 * * * \\
(5.83)\end{array}$ & 0.000 \\
\hline Total Assets & $\begin{array}{c}-0.007 * * \\
(-2.11)\end{array}$ & 0.007 & $\begin{array}{c}-0.027 * * \\
(-2.07)\end{array}$ & 0.013 & $\begin{array}{c}-0.028 * * * \\
(-3.53)\end{array}$ & 0.007 \\
\hline NPVAR & $\begin{array}{c}0.036 * * \\
(2.35)\end{array}$ & 0.101 & $\begin{array}{c}0.009 * * \\
(2.96)\end{array}$ & 0.003 & $\begin{array}{c}0.008 * * * \\
(4.35)\end{array}$ & 0.002 \\
\hline FCFVAR & $\begin{array}{l}-0.253 \\
(-0.93)\end{array}$ & 0.272 & $\begin{array}{l}-0.038 \\
(-0.95)\end{array}$ & 0.039 & $\begin{array}{l}-0.018 \\
(-0.44)\end{array}$ & 0.041 \\
\hline divPOUT & $\begin{array}{l}-0.005 \\
(-1.20)\end{array}$ & 0.004 & $\begin{array}{l}-0.008 \\
(-1.39)\end{array}$ & 0.005 & $\begin{array}{c}-0.012 * * \\
(-2.96)\end{array}$ & 0.004 \\
\hline Q & $\begin{array}{c}-0.193 * * * \\
(-6.77)\end{array}$ & 0.029 & $\begin{array}{c}-0.199 * * * \\
(-3.53)\end{array}$ & 0.056 & $\begin{array}{c}-0.047 * * * \\
(-3.63)\end{array}$ & 0.013 \\
\hline InterQ & $\begin{array}{c}0.043 * * * \\
(9.22)\end{array}$ & 0.005 & $\begin{array}{c}0.042 * * * \\
(4.25)\end{array}$ & 0.009 & $\begin{array}{c}0.001 * * * \\
(5.79)\end{array}$ & 0.000 \\
\hline Industrials & $\begin{array}{l}0.001 \\
(0.02)\end{array}$ & 0.023 & $\begin{array}{l}-0.035 \\
(-0.76)\end{array}$ & 0.046 & $\begin{array}{l}-0.010 \\
(-0.38)\end{array}$ & 0.026 \\
\hline Health Care & $\begin{array}{l}0.006 \\
(0.25)\end{array}$ & 0.025 & $\begin{array}{l}0.029 \\
(0.35)\end{array}$ & 0.083 & $\begin{array}{l}0.044 \\
(1.26)\end{array}$ & 0.035 \\
\hline $\begin{array}{l}\text { Consumer } \\
\text { Services }\end{array}$ & $\begin{array}{l}-0.018 \\
(-0.77)\end{array}$ & 0.023 & $\begin{array}{l}0.017 \\
(0.24)\end{array}$ & 0.072 & $\begin{array}{l}-0.010 \\
-0.34)\end{array}$ & 0.029 \\
\hline Technology & $\begin{array}{c}0.124 * * * \\
(3.91)\end{array}$ & 0.031 & $\begin{array}{l}-0.032 \\
(-0.33)\end{array}$ & 0.096 & $\begin{array}{c}0.183 * * * \\
(5.00)\end{array}$ & 0.036 \\
\hline Financials & $\begin{array}{c}0.055 \dagger \\
(1.87)\end{array}$ & 0.029 & $\begin{array}{l}-0.002 \\
(-0.03)\end{array}$ & 0.048 & $\begin{array}{l}0.026 \\
(0.89)\end{array}$ & 0.029 \\
\hline $\begin{array}{l}\text { Consumer } \\
\text { Goods }\end{array}$ & $\begin{array}{c}0.043 * * \\
(1.98)\end{array}$ & 0.022 & $\begin{array}{l}-0.079 \\
(-1.08)\end{array}$ & 0.073 & $\begin{array}{l}-0.015 \\
(-0.45)\end{array}$ & 0.034 \\
\hline Oil \& Gas & $\begin{array}{l}-0.016 \\
(-0.75)\end{array}$ & 0.021 & $\begin{array}{l}0.064 \\
(0.65)\end{array}$ & 0.098 & $\begin{array}{l}0.054 \\
(1.37)\end{array}$ & 0.039 \\
\hline $\begin{array}{c}\mathrm{R}^{2} \\
\left(\mathrm{Adj} . \mathrm{R}^{2}\right)\end{array}$ & $\begin{array}{c}0.54 \\
(0.51))\end{array}$ & & $\begin{array}{c}0.53 \\
(0.45)\end{array}$ & & $\begin{array}{c}0.35 \\
(0.32)\end{array}$ & \\
\hline $\begin{array}{c}\text { Wald } \\
\chi^{2}(14)\end{array}$ & $\begin{array}{c}250.31 * * * \\
(0.000)\end{array}$ & & $\begin{array}{c}34.93 * * \\
(0.001)\end{array}$ & & $\begin{array}{c}127.45 * * * \\
(0.000)\end{array}$ & \\
\hline $\begin{array}{c}\text { Sample } \\
\text { Size }\end{array}$ & 232 & & 100 & & 332 & \\
\hline
\end{tabular}

$\dagger, * *, * * *$ denote significance at $10 \%, 5 \%$ and $1 \%$ respectively 
The regression estimates for the US is provided in column 2, Australia in column 3 and combined data in column 4 in Table 4. Results show that a CEO's payout (PayoutFactor) is statistically significant at $1 \%$ level, thus indicate that existence of golden parachutes increases the level of net cash balance in firms. There are a number of plausible reasons for this outcome. First, CEOs are attracted to extremely large payouts under a change in control payments and therefore alter their firm's cash balances in order to entice a potential acquirer. A higher cash balance helps to offset the costs of acquisition, thus increasing the likelihood of a takeover and likelihood of a CEO getting paid out. This explanation is consistent with view provided by Jensen (1986) that managers are predominantly self-seekers or it is a reward for social status (Domhoff, 1978; Ratcliff, 1980). Second view is that firms with greater cash balances are more likely to offer large change in control payouts because they have the cash balances to do so. This explanation supports the view that change in control payment may exists to gain access to executive talent (Morrison, 1982; Maurer, 1984). Third view is that firms tend to hold larger cash balances to offset their own internal risks due to volatile cash flows (Miller and Orr, 1966; Karni, 1973). Having large change in control agreements in place for executives would most likely worsen the cash flow volatility as the firm would be required to payout significant amount of cash if CEOs employment is terminated. This view is supported by our results where the coefficient of the earnings volatility (NPVar) is positive and statistically significant at the $5 \%$ and $1 \%$ level, respectively. This indicates that high earnings volatility leads to higher net cash balances.

The firm performance measure Tobin's $\mathrm{Q}$ has a negative coefficient and is statistically significant at 1 per cent level. This shows that Tobin's Q has a negative effect on the net cash balances. Firms may have invested more resources to increase value which may have required using cash. However, the coefficient of the InterQ (interaction between PayoutFactor and Tobin's Q) is positive and statistically significant at 1 per cent and 10 per cent, respectively. The results for InterQ indicate that as value of the firm increases, the CEOs expected payout also increases.

Results for the industry dummy variables are interesting to note. Result for the US show that technology, financials and consumer goods sectors have positive coefficients and are statistically significant at 1 per cent, 5 per cent and 10 per cent. This suggests that firms in these industries hold more cash compared to other industries. A plausible reason could be that these industries have long lag time between research and payouts which may require them to hold a greater amount of cash than similar sized firms in other industries.

In investigating which of the three explanations stated above holds the greatest weight, we examine the firm's capital structure as the second attractiveness variable, that is, how much of the firm's assets are owned by firm's equityholders. A firm with more equity is considered more attractive as a takeover target as the acquiring firm can increase the amount of debt in a firm in order to raise cash after the costly acquisition process. 
Table 5. Equity Percentage Regression Estimate

\begin{tabular}{|c|c|c|c|c|c|c|}
\hline & U.S & $\begin{array}{c}\text { Bootstrap } \\
\text { Std. } \\
\text { Errors }\end{array}$ & AUS & $\begin{array}{c}\text { Bootstrap } \\
\text { Std. } \\
\text { Errors }\end{array}$ & Combined & $\begin{array}{c}\text { Bootstrap } \\
\text { Std. } \\
\text { Errors }\end{array}$ \\
\hline Intercept & $\begin{array}{c}1.037 * * * \\
(7.76)\end{array}$ & 0.134 & $\begin{array}{c}1.140 * * * \\
(5.82)\end{array}$ & 0.177 & $\begin{array}{l}1.27 * * * \\
(10.62)\end{array}$ & 0.120 \\
\hline $\begin{array}{l}\text { Payout } \\
\text { Factor }\end{array}$ & $\begin{array}{c}-0.001 * * * \\
(-2.28)\end{array}$ & 0.000 & $\begin{array}{c}-0.006 * * * \\
(-3.36)\end{array}$ & 0.014 & $\begin{array}{c}-0.011 * * * \\
(-8.01)\end{array}$ & 0.000 \\
\hline Total Assets & $\begin{array}{c}-0.037 * * * \\
(-4.80 *\end{array}$ & 0.008 & $\begin{array}{c}-0.035 * * \\
(-2.62)\end{array}$ & 0.013 & $\begin{array}{c}-0.058 * * * \\
(-8.04)\end{array}$ & 0.007 \\
\hline NPVAR & $\begin{array}{c}-0.219 * * \\
(-2.05)\end{array}$ & 0.107 & $\begin{array}{l}-0.001 \\
(-0.32)\end{array}$ & 0.002 & $\begin{array}{l}0.001 \\
(0.47)\end{array}$ & 0.003 \\
\hline FCFVAR & $\begin{array}{l}-0.599 \dagger \\
(-1.89)\end{array}$ & 0.317 & $\begin{array}{l}0.000 \\
(0.01)\end{array}$ & 0.041 & $\begin{array}{l}-0.024 \\
(-0.49)\end{array}$ & 0.049 \\
\hline divPOUT & $\begin{array}{l}0.003 \\
(0.69)\end{array}$ & 0.004 & $\begin{array}{l}0.017 \\
(1.51)\end{array}$ & 0.013 & $\begin{array}{l}0.006 \\
(0.68)\end{array}$ & 0.009 \\
\hline $\mathrm{Q}$ & $\begin{array}{c}-0.289 * * * \\
(-9.29)\end{array}$ & 0.031 & $\begin{array}{c}-0.575 * * * \\
(-5.80)\end{array}$ & 0.099 & $\begin{array}{l}0.017 \\
(0.92)\end{array}$ & 0.019 \\
\hline InterQ & $\begin{array}{c}0.061 * * * \\
(12.87)\end{array}$ & 0.005 & $\begin{array}{c}0.098 * * * \\
(6.67)\end{array}$ & 0.014 & $\begin{array}{l}-0.003 \\
(-0.09)\end{array}$ & 0.000 \\
\hline Industrials & $\begin{array}{l}0.013 \\
(0.58)\end{array}$ & 0.023 & $\begin{array}{l}0.035 \\
(0.60)\end{array}$ & 0.058 & $\begin{array}{l}0.011 \\
(0.36)\end{array}$ & 0.032 \\
\hline Health Care & $\begin{array}{l}0.042 \\
(1.18)\end{array}$ & 0.035 & $\begin{array}{l}0.115 \dagger \\
(1.75)\end{array}$ & 1.465 & $\begin{array}{c}0.132 * * \\
(2.85)\end{array}$ & 0.046 \\
\hline $\begin{array}{l}\text { Consumer } \\
\text { Services }\end{array}$ & $\begin{array}{l}0.042 \\
(1.33)\end{array}$ & 0.031 & $\begin{array}{l}0.004 \\
(0.04)\end{array}$ & 0.104 & $\begin{array}{l}-0.017 \\
(-0.30)\end{array}$ & 0.058 \\
\hline Technology & $\begin{array}{c}0.072 * * \\
(1.99)\end{array}$ & 0.036 & $\begin{array}{l}0.009 \\
(0.10)\end{array}$ & 0.087 & $\begin{array}{c}0.176 * * * \\
(3.64)\end{array}$ & 0.048 \\
\hline Financials & $\begin{array}{c}-0.066 * * \\
(-2.40)\end{array}$ & 0.027 & $\begin{array}{l}-0.072 \\
(-1.39)\end{array}$ & 0.052 & $\begin{array}{c}-0.068 * * \\
(-2.03)\end{array}$ & 0.033 \\
\hline $\begin{array}{c}\text { Consumer } \\
\text { Goods }\end{array}$ & $\begin{array}{l}-0.002 \\
(-0.05)\end{array}$ & 0.029 & $\begin{array}{l}-0.007 \\
(-0.09)\end{array}$ & 0.074 & $\begin{array}{l}-0.058 \\
(-1.62)\end{array}$ & 0.037 \\
\hline Oil \& Gas & $\begin{array}{c}0.081 * * \\
(2.51)\end{array}$ & 0.032 & $\begin{array}{l}0.105 \\
(1.51)\end{array}$ & 0.069 & $\begin{array}{c}0.129 * * \\
(2.99)\end{array}$ & 0.043 \\
\hline $\begin{array}{c}\mathrm{R}^{2} \\
\left(\text { Adj. } \mathrm{R}^{2} \text { ) }\right.\end{array}$ & $\begin{array}{c}0.69 \\
(0.67)\end{array}$ & & $\begin{array}{c}0.66 \\
(0.61)\end{array}$ & & $\begin{array}{c}0.34 \\
(0.31)\end{array}$ & \\
\hline $\begin{array}{c}\text { Wald } \\
\chi^{2}(14)\end{array}$ & $\begin{array}{c}475.03 * * * \\
(0.000)\end{array}$ & & $\begin{array}{c}177.63 * * * \\
(0.000)\end{array}$ & & $\begin{array}{c}191.04 * * * \\
(0.000)\end{array}$ & \\
\hline Sample Size & 232 & & 100 & & 332 & \\
\hline
\end{tabular}




\section{Macrothink}

The results reported in Table 5 show that PayoutFactor has a negative coefficient and is statistically significant at 1 per cent level in all the three cases (columns 2, 3 and 4 in Table 5). This indicates that as PayoutFactor increases, the total shareholders' equity decreases, therefore, decreasing shareholders voting power. This supports the view that high golden parachutes do alter firm's attractiveness via change in the capital structure. According to Murphy (1999), incumbent managers prefer a firm with debt as this would allow the firm to hold greater total assets which is a primary determinant of executive compensation (Murphy 1999). Since our results reported in Table 5 examine the effects on capital structure and not net cash, we do not provide any explanation for whether high cash balance increases probability for having managerial talent. However, our results do provide support to the third explanation, that is, managers that have greater influence have greater gain from the change in control agreements as an insurance policy. Overall, our results in Table 5 for the analysis of the link between capital structure and change in control payments do support the view that managers can alter their firm's capital structure to attract takeover bids.

Our results are interesting in relation to the results reported by Miller and Modigliani (1963) and Myers and Majluf (1984). Miller and Modigliani state that firms arrive at a target capital structure through the tradeoff play between the lower cost of debt financing and the potential distress costs of bankruptcy. The distress costs are higher in firms with more variable incomes and cash flows. Since our results for both NPVAR and FCFVAR are not significant, it indicates that the distress costs are not relevant for these firms as they hold high cash balances anyway.

The pecking order theory states that firms prefer to fund projects with cash, then debt, before finally issuing equity. Myers and Majluf (1984) suggest that this is due to information asymmetry causing firm's equity to be undervalued. They also suggest that large firms and those with greater dividend payouts suffer less from information asymmetry, thus indicating that there should be a link between firm size, dividend payout and capital structure. Our results show that LnTA has a negative coefficient and is statistically significant at 1 per cent level, indicating large firms tend to have high debt financed compared to equity financed. However, the relationship between dividend payouts and capital structure is not statistically significant, thus providing limited support for Myers and Majluf theory.

Industry specific results show that industrial, healthcare, technology, consumer services and, oil and gas have statistically significant results. The results show that a firm in each of these industries is likely to have a higher equity to debt ratio and thus, more equity financed.

Results for the regression analysis between a firm's attractiveness as a takeover target and the potential payouts available to a CEO under a change in control are reported in Table 6 . The attractiveness factor is a combination of both a firm's net cash balance and its capital structure. A firm that is high in both areas will have a higher attractiveness factor.

The results reported in Table 6 (columns 2, 3 and 4) indicate that PayoutFactor has no effect on the firm's attractiveness. Our results reported InterQ is similar to that reported in Table 4. The results indicate that firms with higher firm have higher payout compared to low performing firms. However, the results do indicate that the greatest cause of a firm's 
attractiveness as a takeover target is the industry in which it operates. This is also supported by Schoenberg and Reeves (1999) who reported that merger and acquisition activities are concentrated in a few key industries and economic sectors. Those industries are industrial, healthcare, technology and the oil and gas industries.

Table 6. Attractiveness Factor Regression Estimate

\begin{tabular}{|c|c|c|c|c|c|c|}
\hline & US & $\begin{array}{c}\text { Bootstrap } \\
\text { Std. } \\
\text { Errors } \\
\end{array}$ & AUS & $\begin{array}{c}\text { Bootstrap } \\
\text { Std. } \\
\text { Errors }\end{array}$ & Combined & $\begin{array}{c}\text { Bootstrap } \\
\text { Std. } \\
\text { Errors }\end{array}$ \\
\hline Intercept & $\begin{array}{c}7.019 * * * \\
(11.21)\end{array}$ & 0.626 & $\begin{array}{l}2.228 * * * \\
(8.56)\end{array}$ & 0.260 & $\begin{array}{l}7.57 * * * \\
(10.97)\end{array}$ & 0.690 \\
\hline $\begin{array}{l}\text { Payout } \\
\text { Factor }\end{array}$ & $\begin{array}{l}0.000 \\
(0.44)\end{array}$ & 0.000 & $\begin{array}{l}0.017 \\
(0.69)\end{array}$ & 0.025 & $\begin{array}{l}-0.001 \\
(-0.97)\end{array}$ & 0.000 \\
\hline Total Assets & $\begin{array}{c}-0.167 * * * \\
(-5.16)\end{array}$ & 0.032 & $\begin{array}{c}-0.048 * * \\
(-2.93)\end{array}$ & 0.016 & $\begin{array}{c}-0.268 * * * \\
(-6.67)\end{array}$ & 0.040 \\
\hline NP VAR & $\begin{array}{c}-1.498 * * \\
(-2.04)\end{array}$ & 0.735 & $\begin{array}{l}0.000 \\
(0.02)\end{array}$ & 0.004 & $\begin{array}{l}0.002 \\
(0.12)\end{array}$ & 0.012 \\
\hline FCF VAR & $\begin{array}{l}0.437 \\
(0.30)\end{array}$ & 1.442 & $\begin{array}{l}-0.036 \\
(-0.56)\end{array}$ & 0.065 & $\begin{array}{l}-0.017 \\
(-0.07)\end{array}$ & 0.236 \\
\hline divPOUT & $\begin{array}{l}-0.008 \\
(-0.46)\end{array}$ & 0.017 & $\begin{array}{l}0.001 \\
(0.11)\end{array}$ & 0.007 & $\begin{array}{l}-0.041 \\
(-1.27)\end{array}$ & 0.033 \\
\hline Q & $\begin{array}{c}-2.562 * * * \\
(-10.62)\end{array}$ & 0.241 & $\begin{array}{c}-0.666 * * * \\
(-8.29)\end{array}$ & 0.080 & $\begin{array}{c}-0.197 * * \\
(-2.84)\end{array}$ & 0.069 \\
\hline InterQ & $\begin{array}{c}0.503 * * * \\
(14.69)\end{array}$ & 0.034 & $\begin{array}{c}0.122 * * * \\
(8.30)\end{array}$ & 0.015 & $\begin{array}{c}0.001 \dagger \\
(1.93)\end{array}$ & 0.000 \\
\hline Industrials & $\begin{array}{c}0.333 * * * \\
(3.07)\end{array}$ & 0.108 & $\begin{array}{l}-0.058 \\
(-0.76)\end{array}$ & 0.077 & $\begin{array}{l}0.207 \\
(0.97)\end{array}$ & 0.214 \\
\hline Health Care & $\begin{array}{c}0.559 * * * \\
(3.49)\end{array}$ & 0.160 & $\begin{array}{l}0.188 \\
(1.39)\end{array}$ & 0.135 & $\begin{array}{c}1.085 * * * \\
(3.97)\end{array}$ & 0.273 \\
\hline $\begin{array}{l}\text { Consumer } \\
\text { Services }\end{array}$ & $\begin{array}{c}0.483 * * * \\
(3.89)\end{array}$ & 0.124 & $\begin{array}{l}0.109 \\
(1.32)\end{array}$ & 0.083 & $\begin{array}{c}0.416 \dagger \\
(1.66)\end{array}$ & 0.250 \\
\hline Technology & $\begin{array}{c}0.765 * * * \\
(5.19)\end{array}$ & 0.147 & $\begin{array}{l}-0.157 \\
(-1.10)\end{array}$ & 0.143 & $\begin{array}{c}1.548 * * * \\
(6.48)\end{array}$ & 0.239 \\
\hline Financials & $\begin{array}{l}0.069 \\
(0.59)\end{array}$ & 0.116 & $\begin{array}{l}-0.097 \\
(-1.47)\end{array}$ & 0.066 & $\begin{array}{l}-0.047 \\
(-0.24)\end{array}$ & 0.198 \\
\hline $\begin{array}{c}\text { Consumer } \\
\text { Goods }\end{array}$ & $\begin{array}{c}0.484 * * * \\
(3.13)\end{array}$ & 0.154 & $\begin{array}{l}-0.008 \\
(-0.10)\end{array}$ & 0.086 & $\begin{array}{l}0.112 \\
(0.46)\end{array}$ & 0.246 \\
\hline Oil \& Gas & $\begin{array}{c}0.589 * * * \\
(3.79)\end{array}$ & 0.156 & $\begin{array}{l}-0.010 \\
(-0.13) \\
\end{array}$ & 0.084 & $\begin{array}{c}0.885 * * * \\
(3.32) \\
\end{array}$ & 0.266 \\
\hline $\mathrm{R}^{2}$ & 0.88 & & 0.73 & & 0.37 & \\
\hline$\left(\operatorname{Adj} . R^{2}\right)$ & $(0.87)$ & & $(0.69)$ & & $(0.34)$ & \\
\hline Wald & $1294.87 * * *$ & & $195.10 * * *$ & & $263.61 * * *$ & \\
\hline$\chi^{2}(14)$ & $(0.000)$ & & $(0.000)$ & & $(0.000)$ & \\
\hline Sample Size & 232 & & 100 & & 332 & \\
\hline
\end{tabular}


In summary, results reported in Table 4 and 5 provide support to our hypothesis that executives who stand to gain substantially from an acquisition would actively seek to make their firms more attractive to a takeover bid. Our results provide support to the results reported by Larcker and Lambert (1985), Wade and O'Reilly (1990) and Singh and Harianto (1989), that managers use their power to secure their financial future with golden parachutes and change in control payments. Results reported in Table 6 show that the size of an executive's potential change in control payments is unrelated to the firm's attractiveness as a takeover target. Total assets are negatively related to both equity and cash and NPVar is statistically significant in explaining cash balance levels.

\section{Conclusion}

Using agency theory paradigm, Larcker and Lambert (1985) and Narayan and Sundaram (1998) argue that change in control payments exist primarily as an insurance policy for incumbent managers, should their firm ever be acquired. This view is also supported by Whisler (1984), Drucker (1974) and Lorsch (1989) who argue that executives are in complete control of firms and that shareholder and boards of directors are powerless. According to Hartzell et al. (2004), since the inception of golden parachutes, change in control payments have become a significant source of executive compensation during a takeover with some CEOs receiving up to nine times their annual salary. This study investigates whether change in control payments motivates some CEOs to actually desire their firm to be taken over.

Using the US and Australian data, and employing OLS regression, we report that the firms with large change in control payments also tend to have large cash balances. This view is also supported by Hartzell et al. (2004). Our findings reported in Table 4 show that an increase in PayoutFactor (golden parachute provision) tends to have a positive effect on net cash balance, indicating that firms do hold high cash balances in order to be able to meet their obligation. However, results for total assets indicate that smaller firms hold higher net cash balances compared to larger firms. Earnings volatility (NPVAR) is positive, thus indicating that firms experiencing high volatility tend to hold higher net cash balances. Results reported in Table 5 indicate that FactorPayout has a negative effect on the proportion of equity held by the shareholders. This suggests that managers do change the capital structure of the firm (proportion of debt and equity) in order to gain power of control. Our findings reported in Tables 6 support the view that managers that have substantial influence over their firms actually use this influence to get their firms to hold more cash and negotiate better change in control contracts. This enables the incumbent manager to use the extra cash for their personal use but also insure that their financial wellbeing is secured should the firm ever be acquired.

We conclude that firms with greater cash levels offer change in control agreements as they are more able to afford them and having high golden parachute benefits allow CEOs to change the firms' capital structure for their own benefits. Overall, our finding supports the view that change in control agreements are implemented largely due to executives wanting an insurance policy and corporate governance is being relatively powerless to stop them.

Finally, we wish to caution people from generalising the findings of this study as it is based on a small sample size. It is noted that this study is timely and deals with concerns regarding 
CEO compensation, capital structure and governance issues. The extent to which companies can work to lift governance practices will provide opportunities for research in the future.

\section{References}

Andrade, G., Mitchell, M., \& Stafford, E. (2001). New evidence and perspectives on Mergers. Journal of Economic Perspectives, 15, 103-120,

Levine, P. \& Aaronovitch, S. (1981). The financial characteristics of firms and theories of merger activity. Journal of Industrial Economics, 30(2), 149-72, http://dx.doi.org/10.2307/2098200

Alcalde, N., \& Espitia, M. (2003). The Characteristics of Takeover Targets: The Spanish Experience 1991-1997. Journal of Management and Governance, 7, 1-26.

Almazan, A. \& Suarez, J. (2004) Entrenchment and severance pay in optimal governance structures. Journal of Finance, 58, 519-547.

Ambrose B., \& Megginson, W. (1992). The role of asset structure, ownership structure, and takeover defenses in determining acquisition likelihood. Journal of Financial and Quantitative Analysis, 27(4), 575-589. http://dx.doi.org/10.2307/2331141

Bebchuk, L., Cohen, A. \& Wang, C. C. Y. (2010). Golden Parachutes and the Wealth of Shareholders. Harvard Law and Economics Discussion Paper 683, http://ssrn.com/abstract $=1718488$

Bowie, C., \& Fischer, J. (1996). Have Parachutes become more than security blankets? Mergers and Acquisitions, 17-22.

Damodaran, A. (2007). The Anatomy of an LBO: Leverage, Control and Value. paper presented at the AIMR Equity Research and Valuation Techniques Conference, 4-5th December, Los Angeles.

DeAngelo, H. \& DeAngelo, L. (2007). Capital structure, payout policy, and financial flexibility. Working paper, Marshall School of Business, University of Southern California.

Devereux, M., \& Schiantarelli, F. (1989). Investment financial factors and cash flow evidence from U.K. panel data, National Bureau of Economic Research Chapter in, Asymmetric Information, Corporate Finance, and Investment, 279-306, National Bureau of Economic Research, Inc.

Domhoff, G. (1978). The power that be: processes of ruling class America. New York: Random House Inc.

Davis, J. H., Schoorman, F. D., \& Donaldson, L. (1997). Towards a stewardship theory of management. Academy of Management Review, 22(1), 20-47, http://dx.doi.org/10.2307/259223

Drucker, P. (1974). Management, tasks, responsibilities, practices. New York: Harper and Row. 
Fowley, C., Hartzell, J., Titman, S., \& Twite, G. (2007). Why do firms hold so much cash? A tax based explanation. Journal of Finance.

Graham, J., \& Harvey, C. (2001). The theory and practice of corporate finance: evidence from the field. Journal of Financial Economics.

Grinstein, Y., \& Hribar, P. (2004). CEO compensation and incentives: evidence from M\&A bonuses. Journal of Financial Economics, 73, 119-143.

Hartzell, J., Ofek, E., \& Yermack, D. (2004). Whats in it for me? CEOs Whose Firms Are Acquired. The Review of Financial Studies, 17(1), 37-61.

Hasbrouck, J. (1985). The characteristics of takeover targets and other measures. Journal of Banking and Finance, 9(3), 351-362, http://dx.doi.org/10.1016/0378-4266(85)90038-X

Helwege, J., \& Liang, N. (1996). Is there a pecking order? Evidence from a panel of IPO firms. Journal of Financial Economics, 40(3), 429-458, http://dx.doi.org/10.1016/0304-405X(95)00851-5

Holland, K., \& Hodgkinson, L. (1994). The pre-announcement share price behavior of UK takeover targets. Journal of Business Finance and Accounting, 21(4), 467-490.

Jensen, M., \& Meckling, W. (1976). Theory of the firm: managerial behavior, agency costs and ownership structure. Journal of Financial Economics, 3, 305-360.

John, T. (1993). Accounting measures of corporate liquidity, leverage and costs of financial distress. Financial Management, 22(3), 91-100, http://dx.doi.org/10.2307/3665930

Knoeber, C. (1986). Golden parachutes, shark repellents and hostile tender offers. American Economic Review, 76(1), 155-167.

Larcker, D., \& Lambert, R. (1985). Golden parachutes, executive decision making and shareholder wealth. Journal of Accounting and Economics, 7, 179-203.

Lehn, K., \& Poulsen, A. (1989). Free Cash Flow and Stockholder Gains in Going Private Transactions, The Journal of Finance, 44, 771-787. http://dx.doi.org/10.2307/2328782

Lorsch, J. (1989). Pawns or potentates: the reality of Americas' corporate boards. Boston. Harvard Business School Press.

Loughran, T., \& Vijh, A., (1997). Do longterm shareholders benefit from corporate acquisitions? The Journal of Finance, 52(5), 1765-1790.

Machlin, J., H. Choe, \& Miles, J. (1993). The Effects of Golden Parachutes on Takeover Activity. Journal of Law and Economics, 36, 861-876, http://dx.doi.org/10.1086/467300

Martin, K., \& McConnell, J. (1991). Corporate performance, corporate takeovers, and management turnover. Journal of Finance, 46(2), 671-687.

Maurer, D. (1984). Golden parachutes - executive compensation or executive overreaching. Journal of Corporation Law, 9, 346. 
Meltzer, A. (1963). The demand for money: the evidence from the time series. The Journal of the Political Economy, 33(131), 288-302. http://dx.doi.org/10.1086/258768

Miller, F., \& Modigliani, M. (1963). Corporate income taxes and the cost of capital. The American Economic Review, 53(3), 433-443.

Miller, M., \& Orr, D. (1966). A model of the demand for money by Firms. The Quarterly Journal of Economics, 80, 413-435, http://dx.doi.org/10.2307/1880728

Morck, R., Shleifer, A., \& Vishny, R. (1989). Do managerial objectives drive bad acquisitions. The Journal of Finance, 35, 31-48. http://dx.doi.org/10.2307/2328808

Morrison A. (1982, December). Those executive bail out deals. Fortune, 13, 82-87.

Murphy, K. J., (1999). Executive compensation in O. Ashenfelter and D. Card (eds.), Handbook of Labor Economics, 3, Amsterdam: North-Holland, 2485-2563.

Myers, S., \& Majluf, N. (1984). Corporate financing and investment decisions when firms have information that investors do not have. Journal of Financial Economics, 13, 187-221. http://dx.doi.org/10.1016/0304-405X(84)90023-0

Narayan, M., \& Sundaram, A. (1998). A safe landing? Golden parachutes and corporate behavior. University of Michigan Business School Working Paper.

Opler, T., Pinkowitz, L., Stulz, R., \& Williamson, R. (1999). The determinants and implications of corporate cash holdings. Journal of Financial Economics, 52, 3-46. http://dx.doi.org/10.1016/S0304-405X(99)00003-3

Palepu, K. (1986). Predicting takeover targets. Journal of Accounting and Economics, 8(1), 3-35, http://dx.doi.org/10.1016/0165-4101(86)90008-X

Pfeffer, J. (1973). Size, composition and function of hospital board of directors. Administration Science Quarterly, 8, 361-378, http://dx.doi.org/10.2307/2391668

Powell, R.G., \& Thomas, H.M. (1994), Corporate Control and Takeover Prediction, University of Essex, Department of Accounting and Financial Management, Working Paper 94/07.

Provan, K. (1980). Board Power and Organizational Effectiveness Among Human Services Agencies. Academy of Management Journal, 23(2), 221-236, http://dx.doi.org/10.2307/255428

Ratcliff, R. (1980). Banks and corporate lending: an analysis of the impact of the internal structure of the capitalist class on the lending behavior of banks. American Sociological Review, 45(4), 553-570, http://dx.doi.org/10.2307/2095008

Scott, J. (1976). A theory of optimal capital structure. The Bell Journal of Economics, 7(1), 33-54, http://dx.doi.org/10.2307/3003189

Simons, T. (2002). Behavioral Integrity: the perceived alignment between a manager's words and deeds as a research focus. Organization Science, 13(1), 18-35. 
Singh, H., \& Harianto, F. (1989). Management board relationships, takeover risk, and the adoption of golden parachutes. The Academy of Management Journal, 32(1), 7-24, http://dx.doi.org/10.2307/256417

Smith, R. (2009, February 7). Greed is Good. The Wall Street Journal.

Tobin, J. (1956). The interest elasticity of transactions demand for cash. The Review of Economics and Statistics, 38, 241-247, http://dx.doi.org/10.2307/1925776

Wade, J., O'Reilly, C.A., III, \& Chandratat, I. (1990), Golden parachutes: CEOs and the exercise of social influence. Administrative Science Quarterly, 35, 587-603, http://dx.doi.org/10.2307/2393510

Whisler, T. (1984). The rules of the game: inside the corporate board room. Homewood, III: Dow-Jones Irwin. 